DOI: 10.17951/lrp. 2017.36.3.209

\title{
Mariusz SAMORAJ
}

Uniwersytet Warszawski

\section{EDUKACJA MIĘDZYKULTUROWA DLA PRZYSZłOŚCI - NA PRZYKŁADZIE ZAJĘĆ AKADEMICKICH, „INTERCULTURAL DIALOGUE” I PROGRAMU ERASMUS}

\begin{abstract}
Abstrakt: Artykuł jest prezentacją kluczowych problemów współczesnej cywilizacji związanych z kryzysem człowieczeństwa, wspólnotowości, koniecznością określenia strategii społecznych życia w społeczeństwach wielokulturowych i kształtowania kultury pokoju. Odwołując się do tragicznych przypadków terroryzmu islamskiego i do konfliktów, których źródłem jest fanatyzm religijny, wskazuję na potrzebę zaangażowania edukacji w kształtowanie tożsamości człowieka i jego kompetencji międzykulturowych, w tworzenie podstaw obywatelskich i życia we wspólnocie w społeczeństwie wielokulturowym. Jako przykłady takich działań edukacyjnych prezentuję autorskie zajęcia „Intecultural Dialogue” na UW (program Erasmus) oraz wykłady i warsztaty artystyczne w Kunstuniversitäat Linz w Austrii dotyczące dialogu kulturowego.
\end{abstract}

Słowa kluczowe: jakość człowieka, kryzys człowieczeństwa, kultura pokoju, edukacja międzykulturowa, edukacja dla wielokulturowości

\section{WPROWADZENIE}

Problematyka jakości współczesnego człowieka jest wyrazem troski zarówno filozofów, socjologów, jak i pedagogów. Refleksja nad sensem bycia człowiekiem i czasem współczesnym, kiedy to ze wzmożoną siłą występuje zjawisko destruktywnej i okrutnej samoalienacji, staje się istotnym nurtem rozważań humanistów. Celem artykułu jest prezentacja kluczowych problemów naszej cywilizacji związanych z kryzysem człowieczeństwa, wspólnotowości, koniecznością określenia strategii społecznych życia w społeczeństwach wielokulturowych i kształtowania kultury pokoju. Terroryzm islamski, wojny religijne i etniczne - to wyzwania dla współczesnej kultury społecznej i edukacji, w szczególności dla edukacji wielo- 
kulturowej i międzykulturowej, które mogłyby pełnić rolę narzędzia humanizacji społeczeństw.

Tragiczne wydarzenia w Paryżu oraz kolejne ataki terrorystyczne po dziś dzień świadczą o tym, że ,świat cofa się w barbarzyństwo” i jest to ostatni sygnał alarmowy dla wspólnoty europejskiej, by zmienić nieskuteczne, błędne formy polityki i edukacji dla wielokulturowości. Prezentuję edukacyjne zobowiązania służące kształtowaniu tożsamości i kompetencji międzykulturowych, tworzeniu podstaw obywatelskości i życia we wspólnocie, w społeczeństwach wielokulturowych, na przykładzie autorskich zajęć „Intecultural Dialogue” na UW, w których uczestniczą także studenci w ramach programu Erasmus, oraz wykłady i warsztaty artystyczne w Kunstuniversitäat Linz w Austrii dotyczące dialogu kulturowego.

Jako metoda badawcza posłużyła obserwacja uczestnicząca w trakcie zajęć akademickich „Intecultural Dialogue” i zajęć prowadzonych w Kunstuniversitäat Linz w ramach wymiany wykładowców. Wnioski formułowane są również na podstawie swoistego badania $\mathrm{w}$ działaniu dotyczącego możliwości edukacyjnych zajęć artystycznych i zajęć z zakresu społeczno-wychowawczej funkcji sztuki $\mathrm{w}$ upowszechnianiu idei dialogu kultur i wychowania dla pokoju.

\section{WYMIARY DUCHOWEGO I MORALNEGO UPADKU LUDZI WSPÓŁCZESNYCH}

Peter Sloterdijk w książce Krytyka cynicznego rozumu prezentuje wymiary duchowego i moralnego upadku ludzi współczesnych:

Współczesny cynik to postać masowa, unika wyróżniania się i bycia autsajderem. Wtapia się w tłum, jest każdym i nikim, produktem masowych miast i masowych mediów. Pod względem psychologicznym dzisiejszy cynik jest melancholikiem, który potrafi ukrywać swe depresyjne lęki przede wszystkim po to, by utrzymać się na rynku pracy. Wszystko inne się nie liczy. Być to znaczy być na powierzchni (Sloterdijk 2008, s. XII).

W tej perspektywie trudno o altruizm, odruchy solidarności, postawy aktywne, obywatelskie, protest przeciwko ludzkiej krzywdzie, masowym zbrodniom dzisiejszych „nekrofilów”.

W refleksji na temat jakości życia współczesnego człowieka uwzględniać należy perspektywę dramatycznych wydarzeń społeczno-politycznych zachodzących w świecie, grożących konfliktem zbrojnym w skali globalnej - to obowiązek współczesnego pedagoga-humanisty. Punkty zapalne dla globalnego konfliktu tlą się od dawna 
w różnych rejonach świata. Powody ich istnienia są bardzo zróżnicowane: od „zderzeń cywilizacyjnych", na które wskazywał Samuel Huntington (1998), przez odradzające się nacjonalizmy, fundamentalizmy religijne do przejawów kultury odrzucenia, którą krytykuje papież Franciszek oraz kryzysu człowieczeństwa i wspólnotowości w wymiarze ogólnoludzkim - jednej z najpowszechniejszych „chorób” naszego świata.

\section{WYMIARY KRYZYSU CZŁOWIECZEŃSTWA W PERSPEKTYWIE AKTUALNYCH TRAGICZNYCH WYDARZEŃ SPOEECZNO-POLITYCZNYCH}

Oto kilka przykładów wydarzeń kluczowych dla współczesności: kanclerz Niemiec Angela Merkel spotkała się z prezydentem USA Barackiem Obamą (9 lutego 2015 roku), by obradować na temat Państwa Islamskiego szerzącego ludobójstwo i współodpowiedzialnego za terroryzm w Europie, m.in. za atak na redakcję pisma satyrycznego „Charlie Hebdo”, w którym śmierć poniosło 12 osób. Rozmowy dotyczyły także wojny na Ukrainie, z trudem broniącej się przed zbrojną przemocą imperialną Rosji. W rozmowach tych kanclerz Merkel wyraziła intencję, by USA nie dozbrajało Ukrainy, bo wojna rosyjsko-ukraińska może „rozlać się” na Europę. Widać więc, że ład europejski i idea wspólnej Europy są zagrożone, a przywódcy będą podejmować decyzje, które mają ogromny wpływ na dalsze losy całego świata, a nie tylko jego wybranych regionów.

Kolejny akt terroru Państwa Islamskiego to atak na bezbronnych turystów w muzeum Bardo w Tunisie - zginęło ponad 20 osób, w tym Polacy. Był to przede wszystkim atak na młode demokratyczne państwo tunezyjskie. Komentatorzy określają tę zbrodnię jako kontynuację dżihadu „islamskich faszystów”, którzy wojnę religijną chcą rozciągnąć na cały świat. Tragiczne doniesienia z Paryża, gdzie zginęło 130 niewinnych ludzi w ataku terrorystycznym i kolejne akty terroru po dzień dzisiejszy dopełniają wymiaru grozy i absurdu naszego czasu.

Komentując atak na redakcje „Charlie Hebdo”, francuski filozof Alain Finkielkraut pisze:

Nienawiść do muzułmanów powinna być zwalczana, a nawet ścigana prawnie. Ale nie możemy udawać, że terroryzm czy przemoc nie mają żadnego związku z islamem. A tak stwierdził ostatnio prezydent Hollande. [...] Niektórzy powiadają, że problem z Talibami polega na tym, że słabo znają islam. Moim zdaniem, problem jest dokładnie odwrotny: Talibowie nie znają niczego poza islamem. To chyba dobry dowód na to, że islamistyczna przemoc nie spadła z nieba. Integracja imigrantów jest dziś wielkim problemem Francji (Finkielkraut 2015, s. 52). 
Skrajna prawica najgłośniej wypowiada się przeciwko islamowi w Europie. Marine Le Pen robi to we Francji, a PEGIDA (Patriotische Europäer gegen die Islamisierung des Abendlandes) w Niemczech. Warto zachować czujność i nieufność wobec PEGID-y, w której są osoby z nostalgicznym stosunkiem do nazizmu, co podkreśla Finkielkraut, pisząc:

Rozumiem rewoltę przeciwko dominującej w Europie orientacji, zgodnie z którą powodem do chwały ma być nie nasza kultura, lecz nasz szacunek do innych kultur. A już zwłaszcza tych, które nie szanują naszej. Te rewoltę wyrażał doskonale transparent jednego z manifestantów PEGIDY: „Szacunek, równość tolerancja - również dla mojego ludu" (Finkielkraut 2015, s. 53).

Nasuwa się smutna refleksja, iż okrucieństwa XX wieku niczego ludzkości nie nauczyły, a XXI wiek również jest naznaczony piętnem „regresu człowieczeństwa”. $\mathrm{Na}$ ten temat cytowany francuski filozof i eseista wypowiada się następująco:

Stulecie, które w ciągu sześćdziesięciu lat doświadczyło dwóch wojen światowych, totalitaryzmów prawicowych jak i lewicowych, hitleryzmu i stalinizmu, Hiroszimy gułagu, ludobójstwa Auschwitzu i Kambodży, nie można już dłużej, jak to podkreślają Levinas i Ricoeur, tłumaczyć ani łagodzić zła, uznając je za część ogólnego planu. Nasz wiek jest czasem w najwyższym stopniu czasem niepotrzebnego cierpienia, które nie wymaga dialektycznych wyjaśnień, ale czeka na to, by je ukoić - jeśli to możliwe-poprzez bezpośrednią i wolną od wszelkich apriorycznych założeń pomoc. [...] Jeżeli jednak również ta nowa odmiana filantropii, pozbawionej już teraz klapek na oczach, stwarza problem to dlatego, że i ona nie zerwała z okrucieństwem. Raz się sparzywszy, człowiek woli zarezerwować swój humanitaryzm wyłącznie dla wielkiej tragedii. Oznacza to, że potrzeba niemało krwi, aby przełamać jego powściągliwość i zmusić do działania. Jest go w stanie poruszyć jedynie jakaś niezaprzeczalna masakra i całkowicie bierne cierpienie. Dopóki zło nie ukaże się w całej oczywistości, dopóki nie zostaną rozwiane wszelkie zastrzeżenia i wątpliwości, trzyma się na uboczu. Potem zaś ma już co innego na głowie. Nielitościwa to zaiste delikatność. $\mathrm{W}$ ostatecznym rozrachunku w tej uczuciowej alienacji wobec nędzy jest tyle samo okrucieństwa w męskiej decyzji, aby skończyć z nędzą tego świata, odwołując się do sprytnych argumentów rozumu (Finkielkraut 1999, s. 99-100).

Wszystko to świadczy o wielkiej potrzebie humanistycznej refleksji nad możliwościami naprawy spraw ludzkich w świecie początków XXI wieku, zagrożonym kolejną wojną globalną. Naprawianie ludzkości, pisze Finkielkraut, powinno się zacząć od przywrócenia człowiekowi godności ontologicznej. Ludzie nie mogą 
być kamieniami w czyjejś budowli czy ofiarami składanymi na ołtarzach szaleńczych idei. Poprzez akcje humanitarne oraz rozbudzanie wrażliwości na cierpienia przyczyniamy się do lepszej przyszłości rodziny ludzkiej.

Dla pedagogów szczególnie istotne są przyczyny regresu człowieczeństwa i ubożenia kondycji ludzkiej, a także poszukiwanie wychowawczych możliwości przeciwdziałania samoalienacji oraz budowania jakości życia człowieka. Aktualne, nawet po kilkudziesięciu latach, refleksje na ten temat pozostawił Erich Fromm (1991). Pisał on bowiem o dwóch sprzecznych tendencjach konkurujących ze sobą w człowieku: postawie nekrofilii (miłości śmierci) i biofilii (miłości życia). Według Fromma należy mówić o toczącej się w jednostce wojnie pomiędzy tymi dwoma siłami. Gdy zwycięży nekrofilia, spowoduje tragiczne w skutkach konsekwencje dla ludzkiej rodziny, czego doświadczyliśmy w XX wieku. Według Fromma przykładami takich nekrofilnych skrajności są postawy Hitlera i Stalina.

Osoba nekrofilna to ktoś, kogo pociąga i fascynuje wszystko, co martwe.

Nekrofile lubują się w przeszłości. Ich uczucia są podstawowej mierze sentymentalne. Pielęgnują oni w pamięci uczucia, które przeżywali wczoraj, lub te, co do których wierzą, że je przeżywali. Są zimni, zdyscyplinowani, oddani sprawie „praw i porządku”. Wartości, które uznają, są dokładnie odwrotnością tych, które zwykle wiążemy z normalnym życiem: nie życie, lecz śmierć ekscytuje i zaspokaja ich (Fromm 1991, s. 9).

Fromm przedstawia nekrofila jako zakochanego w przemocy. Dla miłośnika życia podstawową polaryzacją jest różnica między kobietą a mężczyzną, dla miłośnika śmierci istnieją dwie płcie: silni i bezsilni, zabijający i zabijani. Kocha zabijających i nienawidzi zabijanych.

Biofilia wyraża się w procesach cielesnych danej osoby, w jej uczuciach, jej gestach; orientacja biofilna wyraża się w całym człowieku. Najbardziej charakterystyczna forma tej orientacji wyraża się w skłonności wszystkich żywych organizmów do życia. [...]. Dążność do ochrony życia i walka przeciw śmierci są najbardziej elementarnymi formami orientacji biofilijnej, wspólnej wszystkim żywym organizmom. Ponieważ jest to dążność do ochrony życia i walki ze śmiercią, stanowi tylko jeden aspekt sprawy. Drugi aspekt ma charakter bardziej pozytywny: żywe istoty mają skłonność do integrowania się, do pojednania; dążą one do łączenia się z innymi przeciwnymi jednostkami, do rozwoju w strukturalnie uporządkowany sposób (Fromm 1991, s. 13-14).

Pełny rozwój biofilii przejawia się orientacją produktywną. Osobę, która w pełni kocha życie, pociąga proces życia we wszystkich jego sferach. Woli ona budować, niż zachowywać $w$ niezmienionym stanie. Jest zdolna dziwić się i przedkłada 
postrzeganie nowego nad bezpieczeństwo konstatowania, że stare jest zachowane. Przedkłada przygody nad pewność. Jej podejście do życia jest raczej funkcjonalne aniżeli mechaniczne. Widzi raczej całość niż część, struktury niż sumy elementów. Pragnie przekształcać i wpływać przez miłość, rozum, własnym przykładem, a nie siłą; nie przez dzielenie rzeczy na kawałki, nie biurokratycznym sposobem administrowania ludźmi, tak jakby byli rzeczami. Cieszy się życiem we wszystkich jego przejawach i radość tę ceni bardziej od zwykłego podniecenia (Fromm 1991, s. 15).

Biofilijna świadomość motywowana jest dążeniem do życia i radości; wysiłek moralny polega na wzmacnianiu miłującej życie strony w sobie. Dlatego też biofil nie pogrąża się w wyrzutach sumienia i poczuciu winy, które w ostatecznym rozrachunku są tylko przejawami samoograniczenia i smutku. Szybko zwraca się w stronę życia i stara się czynić dobro.

Refleksje Fromma dostarczają nam wielu ważnych punktów odniesienia w badaniach nad kondycją współczesnego człowieka, przejawami jego alienacji i możliwościami wzrastania w człowieczeństwie. W poszukiwaniach przyczyn jego upadku zobowiązani jesteśmy do podejmowania dyskusji z różnorodnymi teoriami i do polemiki z rozmaitymi stanowiskami na temat miejsca i roli człowieka we współczesnym świecie. Jednym $\mathrm{z}$ takich stanowisk jest reprezentowany m.in. przez Rosi Braidotti posthumanizm.

Koncepcja posthumanizmu omawiana w książce Po człowieku (Braidotti 2014) budzi wiele moich wątpliwości i rodzi mnóstwo pytań. Zapewne także innym pedagogom, którzy od lat zajmują się edukacją humanistyczną czy pedagogiką kultury, wątpliwości i pytania dotyczące tej kwestii nie są obce. Braidotti kreśli wizję nauki i świata po końcu niepodzielnej dominacji człowieka jako pana natury i twórcy techniki, analizuje wzajemne zależności między światem ludzi a światem zwierząt oraz między światem ludzi a światem maszyn, argumentując, że rzeczywistości tych nie można już od siebie dłużej rozdzielać i hierarchizować zgodnie z obowiązującymi od wieków zasadami. Autorka dzieli się refleksją nad kondycją myślących i czujących istot w epoce, w której zanikają powoli dotychczasowe podziały zorientowane na wyjątkowość człowieka w przyrodzie. Poszukuje dla niego nowego miejsca i nowych zadań oraz określa go mianem podmiotu postludzkiego. To nowe miejsce ma sprawić, że będziemy w stanie sprostać wyzwaniom, jakie stawia przed nami współczesność. W refleksji prowadzonej przez Braidotti odnaleźć można wiele pytań prowokujących do namysłu nad jakością życia ludzi w XXI wieku. Autorka sięga do historycznych przypadków upadku człowieka, do „,nocy ludzkości”, podając jako przykłady: ludobójstwa z czasów II wojny światowej, zniszczenia atomowe Hiroszimy i Nagasaki, współczesne brutalne egzekucje. Odwołuje się także do eksponowania ludzkiego okrucieństwa w mediach. Pisze o tym m.in. w następujący sposób: 
Media skupiły się na brutalności, egzekucji i poniżeniu związanym z krążeniem po świecie wizerunków poranionego, krwawiącego ciała Kadafiego; mniej uwagi poświęcono czemuś, co można określić jako postludzki wymiar współczesnej wojny. Potworność końca Kadafiego bez względu na jego własny despotyzm - wystarczy, by zacząć wstydzić się własnej przynależności do gatunku ludzkiego. Pomijanie roli odegranej w jego upadku przez będące dziełem świata rozwiniętego wyrafinowane technologie śmierci drony jest dodatkowym źródłem moralnego i politycznego niepokoju. Współczesne technologie śmierci mają charakter postludzki z racji intensywnego technologicznego zapośredniczenia, dzięki któremu funkcjonują. [...] Czy operatora sterującego dronem Predator z centrum komputerowego w Las Vegas można uznać za pilota? Co odróżnia go od chłopców pilotujących samolot Enola Gay, który zrzucił bombę na Hiroszimę i Nagasaki? Współczesne wojny wzmagają naszą nekropolityczną moc w stopniu, który przekształca ją w materialne zniszczenie ludzkich ciał i populacji. Dodajmy, nie tylko ludzkich. Nekrotechnologie działają w klimacie społecznym zdominowanym przez ekonomię polityczną nostalgii i paranoi (z jednej strony) oraz euforii i egzaltacji z drugiej. Ten maniakalno-depresyjny stan wytwarza liczne wariacje strachu przed nadchodzącą apokalipsą, katastrofą, która zaraz nastąpi. [...] Z powodu tego poczucia zagrożenia głównym społecznym dążeniem jest nie zmiana, ale zachowanie stanu istniejącego lub przetrwanie (Braidotti 2014, s. 57-58).

Braidotti stwierdza, iż opisywane przez nią sytuacje są przykładem kompromitacji człowieka, a w związku z tym głosi także kompromitację i nadchodzący koniec ideałów humanistycznych. W XXI stuleciu, choć minęło zaledwie kilkanaście lat od jego początku, człowiek rzeczywiście skompromitował się wielokrotnie. Jednak istotne wydaje się pytanie o to, czy dyskusji na ten temat nie można toczyć w perspektywie humanizmu, jako wyrazu troski o jakość człowieka, nie usuwając „podmiotu” z perspektywy dyskursu ani w płaszczyźnie filozoficznej, ani tym bardziej pedagogicznej. Jeśli nie można, działalność pedagogiczna traci swój cel - pomaganie człowiekowi w stawaniu się sobą i odkrywaniu swoich powinności wobec świata. Miejsce człowieka zajmuje posthumanistyczny podmiot o trudnych do określenia cechach.

Warto odwołać się do pojęcia humanizmu w ujęciu Bogdana Suchodolskiego, który rozumiał je bardzo szeroko i nie ograniczał się tu jedynie do tradycji historycznych ukształtowanych w starożytności i odrodzeniu. Pisał on:

Nowy humanizm jest obroną człowieka przed niesprawiedliwymi, krępującymi i przytłaczającymi formami rzeczywistości społeczno-kulturalnej. Jest jego wyzwoleniem. Jest przywróceniem człowieka sobie samemu. Ale zarazem jest wolą budowania nowych, słusznych i odpowiednich form, jest siłą pobudzającą rozwój jednostki, 
przeciwstawieniem się pokusom życia łatwego, krytyką bierności i szablonu, uwielbieniem twórczości. Przetwarzanie świata na miarę ludzką i przetwarzanie człowieka według jego własnych ideałów - oto nierozłącznie zespolone dążenia humanizmu (Suchodolski 1935, s. 240).

Powyższy cytat wskazuje na to, że humanizm może być rozumiany przede wszystkim jako sfera odpowiedzialności człowieka za jakość własnego życia i za otaczającą go rzeczywistość i że nie musi to mieć nic wspólnego z próbami usprawiedliwiania jego dominującej, przejawiającej się w instrumentalnym traktowaniu innych istot pozycji w świecie.

\section{EDUKACJA MIĘDZYKULTUROWA JAKO SZANSA NA ROZWIĄZANIE DRAMATYCZNYCH PROBLEMÓW WSPÓŁCZESNYCH SPOŁECZEŃSTW WIELOKULTUROWYCH}

Proponuję powrót do inspirujących rozważań Komisji Edukacji i Kultury Komitetu Prognoz „Polska w XXI wieku” opublikowanych w pracy Strategia obrony i rozwoju cywilizacji humanistycznej (Suchodolski 1997), aby opracować współczesną strategię obrony człowieka i świata w perspektywie odrodzenia wartości ludzkich, koncepcji człowieka jako homo creator i homo amare. Chodzi tu o strategię tworzenia cywilizacji alternatywnej wobec zdominowanej przez nastawioną na konsumpcjonizm i pustą aksjologicznie wolnorynkową gospodarkę, w której wszystko staje się towarem: nauka, sztuka, technika i sam człowiek. Za jeden z najważniejszych elementów takiej strategii należy w moim przekonaniu uznać edukację międzykulturową.

Tadeusz Lewowicki określa edukację międzykulturową jako:

[...] edukację przybliżającą wiedzę o Innych i ich kulturach, służącą zbliżaniu ludzi różnych narodowości, ras, grup etnicznych, wyznań czy religii, różnych kultur. Co więcej, edukacja ta sprzyjać ma upowszechnianiu wartości uniwersalnych i wzajemnemu wzbogacaniu kultur, oferowaniu dorobku własnej kultury, czerpaniu z dorobku innych kultur (Lewowicki 2014, s. 31).

Edukacja międzykulturowa pozwala człowiekowi odnaleźć się w świecie, który jest dziś przede wszystkim światem wielokulturowym, i odpowiedzieć na wiążące się z takim stanem rzeczy wyzwania. Jerzy Nikitorowicz podkreśla, że nie niwelując różnic, prowadzi ona do uznania obecności różnych kultur w społeczeństwie i traktowania ich jako czynnika wzajemnego wzbogacania się oraz konfrontowania 
wartości pod wieloma względami niespójnych i przeciwstawnych. Uczy mediacji i rozwiązywania konfliktów, a te umiejętności wydają się dziś absolutnie niezbędne (Nikitorowicz 2009, s. 281).

Rada Europy i Komisja Europejska zaproponowały następującą definicję uczenia się międzykulturowego: jest to

[...] uczenie się o tym, jak postrzegamy innych ludzi, którzy bardzo różnią się od nas. Dotyczy nas. Dotyczy naszych znajomych i przyjaciół oraz tego, jak działamy razem, aby zbudować społeczność, w której panuje sprawiedliwość. Dotyczy więzi, jakie mogą stworzyć między sobą społeczności, aby promować równość, solidarność i szanse dla wszystkich. Pogłębia szacunek i promuje godność w stosunkach między kulturami, zwłaszcza gdy część z nich należy do mniejszości, a pozostałe stanowią większość. [...]. Społeczeństwo międzykulturowe to społeczeństwo, w którym różnorodność traktuje się jako jeden z pozytywnych „aktywów” służących rozwojowi społecznemu, politycznemu i gospodarczemu. Społeczeństwo, które cechuje wysoki poziom interakcji społecznej i wzajemne poszanowanie wartości, tradycji i norm (Nikitorowicz 2009, s. 281).

Włączanie uczenia się dialogu kulturowego do teorii i praktyki edukacyjnej jest potrzebą chwili. Warto wspomnieć raport Jacques’a Delorsa i kluczowe zadanie edukacyjne XXI wieku: „uczyć się, aby żyć wspólnie”. Proces ten wymaga

[...] zwiększenia zdolności do wyposażania ludzi w kompetencję ułatwiającą stawianie czoła różnicom kulturowym i zmianom kulturowym w społeczeństwach w coraz większym stopniu wielokulturowych. Tą nową kompetencją kulturową, równie istotną jak umiejętność czytania, pisania i rachowania, jest alfabetyzm kulturowy, który stał się zwornikiem współczesnego świata, zasadniczym środkiem umożliwiającym wykorzystanie wielorakich form, jakie może przybierać edukacja, niezbędnym narzędziem przezwyciężania „zderzenia ignorancji” (Rabczuk 2013, s. 16).

W Konwencji UNESCO $w$ sprawie ochrony i promowania różnorodności form wyrazu kulturowego odnajdujemy zasady przewodnie edukacji międzykulturowej. Są one następujące:

- zasada pierwsza: edukacja międzykulturowa szanuje tożsamość kulturową uczącego się, zapewniając każdemu nauczanie wysokiej jakości, kulturowo adekwatne;

- zasada druga: edukacja międzykulturowa wyposaża każdego uczącego się w wiedzę, postawy i kompetencje kulturowe niezbędne do aktywnego, pełnego uczestnictwa w życiu społeczeństwa; 
- zasada trzecia: edukacja międzykulturowa wyposaża wszystkich uczących się w wiedzę, postawy i kompetencje, które umożliwią im przyczynianie się do szacunku, zrozumienia i solidarności między jednostkami, grupami etnicznymi, społecznymi, kulturowymi i religijnymi oraz narodami (Rabczuk 2013, s. 18).

Wiktor Rabczuk zwraca uwagę, iż zasady te, a w szczególności zasada druga, powinny być wprowadzone do wstępnego i permanentnego kształcenia nauczycieli w zakresie podstaw edukacji międzykulturowej. Wracając do egzemplifikacji z aktualnych wydarzeń, trzeba stwierdzić, że Wspólnota Europejska musi rozwiązać dramatyczne problemy masowych imigracji z Syrii i krajów dotkniętych terroryzmem islamskim - Iraku, Kurdystanu. W najbliższym czasie Polska stanie przed koniecznością przyjęcia kilku tysięcy imigrantów, co wymaga przemyślanych strategii społecznych i edukacyjnych, by uniknąć błędów, jakie w zakresie polityki dla wielokulturowości popełniły Francja, Belgia czy Niemcy. Zdaniem Merkel powinno się wprowadzić formę kultury przewodniej Leitkultur, by w kraju nie zaczęli rządzić muzułmanie. Takie samo stanowisko zajmuje Marek Orzechowski w książce Mój sąsiad islamista. Kalifat u drzwi Europy (2015). Autor opisuje dramatyczne wydarzenia, jakimi były ataki terrorystyczne we Francji i Belgii oraz ich przyczyny. Uważa, że do aktów terroru doprowadziła błędna polityka w Belgii - w imię tolerancji pozwolono na izolację przybywających grup we własnym etnosie, bez konieczności integracji ze społecznością rodzimą, przyjęcia praw i obowiązków obywatelskich, życia we wspólnocie, w nowej dla nich ojczyźnie. Błędna jest bowiem, podkreśla to Nikitorowicz, zasada „,biernej tolerancji” - „[...] pasywnej tolerancji wobec mniejszości etnicznych. Brak starań wobec zintegrowania imigrantów doprowadził do powstania gett, gdzie w poczuciu wyalienowania dorastają młodzi ludzie, którzy pod wpływem ekstremistycznych organizacji zmieniają się niekiedy w zamachowców" (Nikitorowicz 2013, s. 24).

Orzechowski przestrzega przed dynamicznie rozwijającą się społecznością muzułmańską w Belgii. Państwo to w 2013 przyjęło 17 tysięcy uchodźców, którzy oficjalnie wnioskowali o azyl polityczny. Prawie wszyscy pochodzili z Afganistanu, Iraku, Syrii. Autor zaznacza:

Prędzej czy później dostaną prawo pobytu w kraju. Ilu przysięgło wyprowadzić nas z pogaństwa? Ilu jest gotowych użyć miecza? Może lepiej nie pytać, i tak w 2030 Bruksela ma być miastem muzułmańskim, takie prognozy oparte na realizowanych przez brukselskie uniwersytety badaniach, którym niestety trzeba zaufać. Wystarczy przejrzeć statystyki napływu nowych imigrantów i urodzin w klinikach miejskich. Jakie prawo wtedy będzie porządkować życie mieszkańców? Laickie, zapisane w konstytucji i ustawach oddzielających religię od struktur państwa? Czy inne, boskie, wywiedzione 
z księgi, interpretowane przez bezlitosnych fundamentalistów, z praktykowanym na co dzień szariatem? (Orzechowski 2015, s. 17).

W książce czytamy także:

Na świecie już od dawna prowadzona jest wojna religijna, w której stawką jest albo zniszczenie, albo zwycięstwo islamu. To, że my tak nie uważamy, nie ma znaczenia dla drugiej strony. Radykalny fundamentalistyczny islam jest innego zdania. $\mathrm{Na}$ historycznej skali zdarzeń Państwo Islamskie wychyliło wahadło wstecz o kilkanaście wieków. Pół biedy gdyby tylko w narracji. Rzecz w tym, że ten stary religijny konflikt rozgrywany jest dziś w nowej odsłonie, w naszych dekoracjach, na naszej scenie i naszym kosztem. A także z naszym udziałem (Orzechowski 2015, s. 210-211).

Dlatego niezbędna jest wykorzenienie opacznego rozumienia tolerancji - podstawy dotychczasowej polityki wielokulturowości. Dla islamistów spoiwo stanowi grupa żyjąca w odizolowanych gettach etnicznych. Jednostkowa tożsamość zostaje wpisana w tożsamość wspólnotową, ułatwia odejście od dotychczasowych zakazów i nakazów etycznych na rzecz wyznawania ideologii. Taką sytuację Hannah Arendt określiła jako zjawisko negacji moralności, na miejscu której pojawia się albo religia, albo ideologia.

W Europie konieczna jest nowa strategia działań wspólnotowych wobec zbliżającej się ogromnej nowej fali imigrantów. Działania społeczne, zabezpieczenia socjalno-edukacyjne muszą być podporządkowane nowym paradygmatom związanym z postulatem „uczyć się, aby żyć wspólnie”.

Nikitorowicz proponuje następującą strategię edukacyjną:

[...] obecnie należy zauważyć i określić konieczność realizacji przez szkołę nowych funkcji i zadań wynikających z trudnych procesów kształtowania społeczeństwa wielokulturowego. Należy określić zasady, przedstawić ofertę nowych form i metod, aby wspierać utrzymywanie i budzenie etosu, godności, honoru i dumy z wartości rodzimych i kształtować lojalność do kraju zamieszkiwania. Właśnie w tym procesie niezbędny jest twórczy dialog edukacyjny, ustawiczne negocjacje, a nie dotychczasowa zasada poprawności politycznej, która domagała się z góry bezwarunkowej akceptacji, nawet nie tolerancji, a akceptacji, a jeżeli ktoś zaprezentował odmienne zdanie, często miało miejsce napiętnowanie danej osoby jako rasisty. Stąd wycofywano się z dialogu [...] (Nikitorowicz 2014, s. 24 -25).

Poprawność polityczna nie może być zasadą nowej strategii społecznej, bo często przeczy wizji harmonijnego społeczeństwa i wspólnego dobra. Wspólne dobro 
i wartości humanistyczne, o czym pisze Nikitorowicz, coraz częściej zastępowane są przez interesy grupowe, gdy zaczyna się dogmatycznie strzec swoich wywalczonych praw, swobód, stylu życia. Powstaje więc tożsamość zewnątrzsterowalna, pozbawiona ochrony i otoczki wartości osób znaczących, tożsamość bezbronna i otwarta na bezmyślne i nieodpowiedzialne korzystanie $\mathrm{z}$ ofert konsumeryzmu. Dlatego w procesie edukacji należy zwracać uwagę na powstającą pustkę duchową spowodowaną dominacją gadżetów, fikcji, brakiem odpowiedzialności, ufności, empatii itp. Trzeba również dostrzec pustkę moralną, a w kontekście nowych technologii - dominację komunikacji pośredniej, nieustanny proces reifikacji, manifestowanie nabywania wciąż nowych przedmiotów, manifestowania itp. Chwalenie się zastępnikami kreuje tzw. tożsamość protezy, a rzeczy i ich posiadanie są najważniejszymi punktami odniesienia w definiowaniu samego siebie (Nikitorowicz 2014, s. 27).

\section{EGZEMPLIFIKACJE DZIAŁAŃ PEDAGOGICZNYCH Z ZAKRESU EDUKACJI DLA WIELOKULTUROWOŚCI PRZEZ SZTUKE}

Pragnę przytoczyć przykłady własnych działań pedagogicznych prowadzonych na Wydziale Pedagogicznym UW w ramach autorskich zajęć „Intecultural Dialogue”, w których uczestniczą studenci programu Erasmus, jak też serię wykładów i warsztatów artystycznych organizowanych w ramach wymiany wykładowców w Akademii Sztuk Pięknych w Linz w Austrii w 2011 i 2015 roku.

Celem zajęć „Intecultural Dialogue” jest przygotowanie studentów do studiów zagranicznych i współpracy międzynarodowej w obszarze kultury. W trakcie zajęć koncentrujemy się na dialogu międzykulturowym, który poprzez poznawanie Inności umożliwia porozumienie i współpracę w duchu tolerancji i pokoju wśród ludzi różnych narodowości.

W czasie prowadzonej w języku angielskim dyskusji koncentrujemy się na udzielaniu odpowiedzi na pytania: jak szukać tego, co wspólne w zróżnicowanym kulturowo świecie? jak budować i rozszerzać obszary porozumienia i tolerancji? jak działać na rzecz tworzenia kultury pokoju?

W wymiarze dydaktycznym celem zajęć jest jak najpełniejsza integracja ścieżki merytorycznej ze ścieżką językową. W przebiegu ścieżki merytorycznej studenci poznają następujące obszary:

1. Dialog między kulturami.

2. Podstawy edukacji międzykulturowej.

3. Wybrane zagadnienia z zakresu dialogu międzykulturowego przez sztukę $\mathrm{z}$ „The International Journal of Art \& Design Education” 2005-2016. 
4. Materiały Zrównoważona edukacja - przez sztukę i aktywność twórcza $z$ Europejskiego Kongresu INSEA w Rovaniemi.

Ścieżka językowa zakłada podwyższenie kompetencji językowych słuchaczy (przy założeniu poziomu wyjściowego B2) w zakresie wszystkich sprawności językowych, ze szczególnym naciskiem na umiejętności niezbędne przy posługiwaniu się językiem akademickim. Proces kształtowania tych umiejętności, zarówno w zakresie sprawności receptywnych (czytanie i słuchanie ze zrozumieniem tekstów akademickich), jak i produktywnych (dyskusja, prezentacja, sporządzanie notatek, pisanie streszczeń i referatów), odbywa się na bazie materiałów merytorycznych związanych z tematyką seminarium.

Celem wykładów i warsztatów w Akademii Sztuk Pięknych w Linz w 2011 i 2015 roku była prezentacja aktualnej wiedzy na temat edukacji międzykulturowej przez sztukę w Polsce i na świecie, a także kształtowanie wrażliwości międzykulturowej - podstaw kultury pokoju, kompetencji przyszłych nauczycieli niezbędnych do organizowania dialogu kulturowego.

Doświadczanie Inności poprzez działania wspólnotowe takie jak: taniec, śpiewanie kolęd, np. Cichej nocy w języku polskim, niemieckim, hiszpańskim, irlandzkim/celtyckim, działania plastyczne, np. „Mural Painting for Peace”, warsztaty z zakresu plastyki obrzędowej oraz prezentacje dotyczące kultur (obyczajów, sztuki, języka, etnicznego zróżnicowania uczestników warsztatów), a także dyskusje na temat praktycznych rozwiązań związanych z edukacją dla wielokulturowości i dialogu kultur w poszczególnych krajach stanowiły podstawę zbliżania się do metodyki edukacji wielokulturowej i międzykulturowej.

Kontynuacją akademickich działań w zakresie przedmiotu „Intercultural Dialogue" były wyjazdy zagraniczne w ramach programu Erasmus. Tematyka spotkań ze studentami Kunstuniversitäat Linz 2015 wyglądała następująco:

1. Edukacja międzykulturowa i wychowanie dla pokoju we współczesności oraz warsztat plastyczny „Mural Painting for Peace”.

2. Kultura tradycyjna i twórczość ludowa w Polsce - wykład i warsztat wycinankarski z polskiej wycinanki ludowej różnych regionów połączony z prezentacja tradycji i znaczenia wycinanki żydowskiej.

3. Wychowanie przez sztukę w Polsce - tradycja i teraźniejszość.

4. Szkoły aktywności twórczej - tradycja a teraźniejszość wraz z odniesieniami do praktyki.

Inspiracją dla warsztatów artystycznych „Mural Painting for Peace” była prezentacja multimedialna dotycząca japońskiej inicjatywy artystycznej profesora Toshifumi Abe z Osaka Women’s College „The Guernica Children's Peace Mural Project". 
Projekt „Kids' Guernica” zainicjowano jako ruch na rzecz pokoju w Japonii w 1995 roku, 50 lat po II wojnie światowej i w rocznicę zrzucenia bomb na Nagasaki i Hiroszimę - nową Guernicę. Jest on przeznaczony przede wszystkim dla dzieci i młodzieży, aby definiowały własne pojęcie pokoju przez udział we wspólnym edukacyjnym projekcie oraz brały udział w kolektywnym utrwalaniu aktualnego do dziś przesłania.

Projekt został zainspirowany dziełem słynnego hiszpańskiego artysty Pabla Picassa, który namalował obraz jako protest przeciwko brutalnemu zamachowi bombowemu na miasto Guernica podczas hiszpańskiej wojny domowej. Głównym celem projektu „Kids' Guernica” jest promowanie utrzymywania pokoju między ludźmi na świecie, tworzenia swoistej kultury pokoju poprzez obrazy-przesłania tworzone na wielkich płótnach (takiej samej wielkości jak Guernica Picassa, czyli 3,5 x 7,8 m).

Kolejną inspiracją podczas zajęć, które prowadziłem, była wspólnie odśpiewana przy akompaniamencie gitary piosenka Johna Lennona Imagine i analiza „warunków dla pokoju" zawartych w poetyckich strofach o przesłaniu pacyfistycznym. Ta idealistyczna, znana na całym świecie pieśń śpiewana była na ulicach Nowego Jorku w latach 70., podczas marszów protestacyjnych przeciwko wojnie w Wietnamie, w roku 1980, gdy jej autor został brutalnie zamordowany, oraz po ataku terrorystycznym w Nowym Jorku 11 września 2001 roku.

Wszyscy uczestnicy zajęć, studenci i wykładowcy austriackiej Kunstuniversitäat Linz oraz studenci z Ukrainy i Turcji, poruszeni byli taką właśnie formą inspiracji, wspólnie śpiewali dobrze im znane Imagine, a wykonany przez nich Mural Painting for Peace wielkości Gueriniki Picassa zawierał wiele symboli pacyfistycznych i cytaty z piosenki Johna Lennona. Przedstawiał wizję ludzkiej wspólnoty, miłości, empatii, altruizmu, braterstwa.

Jest to w moim przekonaniu przykład zajęć bardzo potrzebnych w obliczu zmieniającego się świata, a przede wszystkim w obliczu nowych wyzwań, jakie stawia przed nami wielokulturowość. Dają one bowiem możliwość postrzegania ludzkości przez pryzmat dobra wspólnego, jakim jest pokojowe współistnienie wszystkich ludzi na Ziemi.

\section{PODSUMOWANIE}

Edukacja międzykulturowa wpisuje się w strategię budowania cywilizacji, w której jest miejsce na dialog kultur i w której ludzie mogą tworzyć wspólnotę niewykluczającą różnorodności. Miałaby to być cywilizacja wartości zróżnicowanych, ale równocześnie uniwersalnych, cywilizacja „życia pogłębionego przez kulturalne uczestnictwo". 
Konieczne jest więc budowanie społecznych strategii humanizacji życia, poczynając od perspektyw lokalnych, zagrożonych biedą, wojną i barbarzyństwem współczesnym, aż do perspektywy „Ziemi - ojczyzny ludzi”. Potrzeba naprawy spraw ludzkich przez międzynarodową, solidarność, dialog kultur i edukację zarówno regionalną, jak i międzykulturową, realizowaną m.in. dzięki europejskim programom wymiany studentów, nauczycieli i wykładowców, umożliwiającym spotkanie z Innym, uczenie się innych kultur, kształtowanie tożsamości międzykulturowej.

Szczególną troską powinniśmy otoczyć edukację służącą przyszłości wspólnoty europejskiej. Troska o wspólny europejski dom wymaga działań określonych w wielu raportach i programach, m.in. w raporcie Komisji Europejskiej Edukacja dla Europy (1999), który odnosi się do pięciu ważnych obszarów problemowych:

1. Budowa europejskiego obywatelstwa.

2. Wzmacnianie europejskiej konkurencyjności i zabezpieczanie zatrudnienia dzięki edukacji.

3. Utrzymywanie społecznych więzi przez edukację.

4. Możliwości stwarzane przez techniki informacyjne.

5. Zdynamizowanie systemów edukacji.

Europejski problem napływu imigrantów (ponad milion w ostatnim czasie) wymaga nie tylko rozwiązań humanitarnych, ,,odruchów serca” i ludzkiej solidarności, ale także społecznych, nowej strategii dla wielokulturowości. Edukacja w tych procesach powinna zaś pełnić rolę kluczową, budować ład na podstawie europejskiego humanizmu.

Podsumowując rozważania na temat edukacji międzykulturowej dla przyszłości - na przykładzie zajęć akademickich „Intercultural Dialogue” i programu Erasmus - postuluję wprowadzenie do podstawy programowej kształcenia ogólnego treści edukacyjnych z zakresu edukacji regionalnej i międzykulturowej w całym systemie szkolnictwa, a także w ramach obligatoryjnych zajęć na studiach pedagogicznych, aby kształtować tożsamość związaną z ojczyzną regionalną i narodową, ale także tożsamość międzykulturową.

\section{LITERATURA}

Anderson T., 2000, The Guernica Children's Peace Mural Project. “The International Journal of Art \& Design Education”, vol. 19, no. 2, 141-152.

Braidotti R., 2014, Po człowieku. Warszawa, Wydawnictwo Naukowe PWN. Raport Komisji Europejskiej „Edukacja dla Europy” 1999. Warszawa, Wydawnictwo Komitet Prognoz „Polska 2000 Plus”.

Finkielkraut A., 2015, Europa to nie Islam. „Newsweek” (2-8 lutego). 
Finkilelkraut A., 1999, Zagubione człowieczeństwo: esej o XX wieku. Warszawa, PIW. Fromm E., 1991, Wojna w człowieku. Gdańsk, GIW.

Huntington S.P., 1998, Zderzenie cywilizacji i nowy kształt ładu światowego. Warszawa, Wydawnictwo Muza.

Lewowicki T., Ogrodzka-Mazur E., Gajdzica A. (red.), 2013, Kultura w edukacji międzykulturowej - doświadczenia i propozycje praktyczne. Cieszyn-WarszawaToruń, Wydawnictwo Adam Marszałek.

Lewowicki T., 2014, Edukacja wielokulturowa i międzykulturowa - konteksty rodzime (polskie), europejskie i globalne. W: T. Lewowicki, W. Ogniewjuk, E. Ogrodzka -Mazur, S. Sysojewa (red.), Wielokulturowość i edukacja. Warszawa, WSP ZNP.

Nikitorowicz J., 2009, Edukacja regionalna i międzykulturowa. Warszawa, Wydawnictwa Akademickie i Profesjonalne.

Nikitorowicz J., 2017, Etnopedagogika (w przygotowaniu do druku). Kraków, Oficyna Wydawnicza Impuls.

Orzechowski M., 2015, Mój sąsiad islamista. Kalifat u bram Europy. Warszawa, Wydawnictwo Muza.

Rabczuk W., 2013, Komunikacja i dialog między kulturami. W: T. Lewowicki, E. Ogrodzka-Mazur, A. Gajdzica (red.), Kultura w edukacji międzykulturowej - doświadczenia i propozycje praktyczne. Cieszyn-Warszawa-Toruń, Wydawnictwo Adam Marszałek. Sloterdijk P., 2008, Krytyka cynicznego rozumu. Wrocław, Wydawnictwo Naukowe DSW. Suchodolski B., 1935, Nowy humanizm. „Miesięcznik Literatury i Sztuki”, nr 8, 232-240. Suchodolski B. (red.), 1997, Strategia obrony i rozwoju cywilizacji humanistycznej. Warszawa, Wydawnictwo Komitet Prognoz „Polska w XXI wieku”.

\title{
INTERCULTURAL EDUCATION FOR THE FUTURE ON THE EXAMPLE OF THE UNIVERSITY COURSE "INTERCULTURAL DIALOGUE" \\ AND THE ERASMUS PROGRAMME
}

\begin{abstract}
The article is a presentation of basic problems of contemporary civilization, connected with: the crisis of humanity and community, and also the necessity to define social strategies in multicultural societies and education for the culture of peace. Referring to the tragic cases of Islamic terrorism and conflicts originating from religious fanaticism, I point out the need to involve education in shaping human identity and intercultural competences, in creating civic foundations and in living in a community in a multicultural society. As examples of such educational activities I am presenting an authorship course titled "Intercultural Dialogue" - UW Erasmus Programme and also my lectures and artistic workshop the University of Art and Design Linz (Kunstuniversitäat Linz) in Austria - intercultural dialogue.
\end{abstract}

